\title{
Pancreatic Carcinoma: An Overview
}

\author{
Syed Amjad Ali Rizvi ${ }^{1}$ and Mohammad Azfar ${ }^{2 *}$ \\ ${ }^{1}$ Department of Surgery, JN Medical College, AMU, Aligarh, India \\ ${ }^{2}$ Department of Surgery, Al Bustan Speciality Hospital, UAE
}

Submission: January 30, 2017; Published: January 31, 2017

*Corresponding author: M. Azfar, Department of Surgery, Al Bustan Speciality Hospital, Po Box 2419, Musaffah ME 10, Abu Dhabi, Tel: +971-509054553; Email: mazfar@gmail.com

\section{Editorial}

Pancreatic cancer is the $12^{\text {th }}$ most common cancer in the world. The estimated 5-year prevalence of people in the world living with pancreatic cancer is 4.1 per 100,000 . The average lifetime risk of developing a pancreatic carcinoma for both men and women is $1.5 \%$. The number of new cases of pancreatic cancer is 12.4 per 100,000 men and women per year and the number of deaths is 10.9 per 100,000 men and women per year, making it one of the most deadly solid organ tumors of the body [1,2]. Pancreatic ductal adenocarcinoma is by far the most common histologic subtype of pancreatic carcinoma, regardless of the location within pancreas. Other rare histological subtypes include acinar, squamous, pancreatic endocrine neoplasms or tumors of non-epithelial origin [3].

The various proven risk factors for the development of Pancreatic cancer include cigarette smoking (current> past), Diabetes Mellitus, Obesity, Heavy alcohol intake, Chronic Pancreatitis [4]. 10\% of all the pancreatic cancers are hereditary, mostly being associated with syndromes like HNPCC (Hereditary Non Polyposis Colorectal Cancer), Familial Breast cancer associated with BRCA2 mutation, Peutz-Jeghers syndrome, Ataxia-telangiectasia syndrome etc [5]. With recent genetic improvements, kRAS has been identified to be the most common associated genetic abnormality (>95\%). The other commonly associated genetic alterations include p53, p16 and DPC4 [6].

About $66-75 \%$ of patients present with symptoms of obstructive jaundice. Patients with pancreatic carcinoma may also present with pain in upper abdomen/epigastrium/back, anorexia, fatigue, and malaise and weight loss. Patients may also present with features of acute pancreatitis or Gastric outlet obstruction. Unusually present with new-onset Diabetes Mellitus or Anemia from Gastrointestinal blood loss. Palpable nodules in liver, left supraclavicular fossa, periumbilical fossa and pelvis are indicators of advanced disease. CT scan is the single most useful diagnostic and staging modality of choice [7]. It gives very important information aboutintrahepatic \& extra-hepatic ductal dilatation, relationship of tumor with surrounding structures
(Celiac axis, Hepatic artery, SMA and PV-SMV confluence) and any lymphadenopathy. 3D- reconstruction of CT has added to the ability of predicting the resectability of the pancreatic tumors. Tissue diagnosis isn't required prior to an attempt at curative resection, but is necessary prior to neoadjuvant chemotherapy [8].

Patients with mass lesion in CT scan with no evidence of metastasis are primarily candidates for multi-disciplinary approach including surgical intervention, neoadjuvant and adjuvant chemo-radiotherapy with curative intent. Patients with pre-operative jaundice need to be evaluated for any features of cholangitis, as presence of cholangitis mandates re-operative biliary decompression (ERCP guided stenting of CBD). Patients with resectable growth on CT (Normal tissue plane between tumor and all 3 surrounding arteries i.e. SMA, Celiac axis and Common Hepatic Artery, and patent SMV-PV confluence) are primary candidates for Pancreatico-duodenectomy (Whipple procedure). Patients with borderline resectable growth on CT ( $<50 \%$ circumferential encasement of any 1 of 3 surrounding arteries i.e. SMA, Celiac axis and Common Hepatic Artery, or short segment occlusion of SMV-PV with possible reconstruction) are primarily biopsied using EUS guidance and then followed by neoadjuvant chemotherapy.

Multiple neoadjuvant chemoradiation regimens have been used with variable results. Gemcitabine 30 Gy regimen has had significantly better resection rate, partial response rate and median survival. Patients are then re-staged using CT and again evaluated for resectability. If the tumor is resectable post neoadjuvant chemoradiation, patients undergo Whipple procedure. However, if the tumor remains still unresectable, the patients are treated as having unresectable tumors. Patients with unresectable tumors on CT $(>50 \%$ circumferential encasement of any 1 of 3 surrounding arteries i.e. SMA, Celiac axis and Common Hepatic Artery, or occlusion of SMV-PV with no possible reconstruction) need multidisciplinary approach with palliative intent [9]. Patients with jaundice may be offered ERCP-stenting, hepaticojejunostomy, cholecystojejunostomy. 
Patients with duodenal outlet obstruction may be palliated with Gastrojejunostomy, expandable metallic bowel sounds and those with pain may be palliated by opioids, NSAIDs, USG/CT-guided celiac plexus blocks, intra-operative chemical splanchnicectomy $[4,8]$. Various adjuvant therapies have been tried with drugs like 5-flourouracil, Gemcitabine etc. Gemcitabine has been proven to increase median disease free survival from 6.9 to 13.4 months [10]. Many novel agents like Bevacizumab (Angiogenesis inhibitor), Tipifarnib (kRAS inhibitors), Erlotinib (EGFR inhibitor) have been tried with varied success [8]. Finally at the end, even after so many technological advances, the tumorspecific 5 year survival rates are only 15\% for patients with pancreatic carcinoma. Factors affecting survival of pancreatic carcinoma include tumor size of $>3 \mathrm{~cm}$, positive resection margin, histological grade and regional lymph node metastases [11].

\section{References}

1. Pancreatic cancer statistics (2017) World Cancer Research Fund International [Internet]. Wcrf.org.

2. Rebecca Siegel MPH, Deepa Naishadham MA, AhmedinJemal DV (2013) Cancer statistics. CA Cancer J Clin 404: 320-323.

3. Bettschart V, Rahman MQ, Engelken FJ, Madhavan KK, Parks RW, et al. (2004) Presentation, treatment and outcome in patients with ampullarytumours. Br J Surg 91(12): 1600-1607.

4. Wolfgang CL, Herman JM, Laheru DA, Klein AP, Erdek MA, et al. (2013) Recent progress in pancreatic cancer. CA Cancer J Clin 63(5): 318-348.

5. Shi C, Hruban RH, Klein AP (2009) Familial pancreatic cancer. Arch Pathol Lab Med 133(3): 365-374.

6. Rozenblum E, Schutte M, Goggins M, Hahn SA, Panzer S, et al. (1997) Tumor-suppressive pathways in pancreatic carcinoma. Cancer Res 57(9): 1731-1734.

7. Bluemke DA, Fishman EK (1998) CT and MR evaluation of pancreatic cancer. Surg Oncol Clin N Am 7(1): 103-124.

8. Wolfgang CL, Schulick RD, Cameron JL (2013) Cancers of theperiampullary region and the pancreas. In: Zinner MJ, Ashley SW (Eds.). Maingot's Abdominal Operations $\left(12^{\text {th }}\right.$ edn), McGraw Hill, Philadelphia, USA, pp.1187-1209.

9. National Comprehensive Cancer Network (NCCN) (2016) NCCN Clinical Practice Guidelines in Oncology. Pancreatic Adenocarcinoma Version 2.2016. National Comprehensive Cancer Network.

10. Raut CP, Evans DB, Crane CH, Pisters PW, Wolff RA (2004) Neoadjuvant therapy for resectable pancreatic cancer. Surgical oncology clinics of North America 13(4): 639-661.

11. Qi-lu Qiao, Yi-guo Zhao, Mu-lin Ye, Yin-mo Yang, Jian-xun Zhao, et al. (2007) Carcinoma of the ampulla of Vater: factorsinfluencing long-

\section{Your next submission with Juniper Publishers} will reach you the below assets

- Quality Editorial service

- Swift Peer Review

- Reprints availability

- E-prints Service

- Manuscript Podcast for convenient understanding

- Global attainment for your research

- Manuscript accessibility in different formats

( Pdf, E-pub, Full Text, Audio)

- Unceasing customer service

Track the below URL for one-step submission https://juniperpublishers.com/online-submission.php 